\title{
大深度低強度地山におけるトンネル設計の合理化
}

\section{RATIONALIZATION OF TUNNEL DESIGN FOR THE LOW STRENGTH DEEP GROUND}

\author{
梨本 裕*・高森貞彦*・今田 徹** \\ By Yutaka NASHIMOTO, Sadahiko TAKAMORI and Toru KONDA
}

\begin{abstract}
This study was carried out to provide the basis for establishing a rational design method where requirements of both safety and economy in tunnel construction for the low strength deep ground are compatible. For the economic consideration of the tunnel construction, excavation works should be taken account as well as the support. Based on ground characteristic curves describing the relation between support pressure and ground displacement, following two curves had been developed for the checking of the design. One describes the relation between ground displacement and excavation limit which had been obtained by the sum of designed inner section, linning thickness and ground displacement. Another describes the relation between construction cost and ground displacement. The result of the study shows a better design indication for minimum excavation limit rather than minimum support pressure.
\end{abstract}

Keywords : deep ground development, ground characteristic curves, minimum support pressure, minimum excavation limit, NATM, shield tunnelling

\section{1. はじめに}

大都市への人口・諸機能の集中，地価の高謄などに伴 い，地下空間利用が注目を集めているが，すでに大都市 中心部の浅度地下は過密状態になっており, 大深度地下 の開発が急務となりつつある。また，人口過疎地におい ても, 地下の遮断性, 耐震性, 耐圧性などを利用するた めに, 高レベル放射性廃棄物の地層処分場やエネルギー 貯蔵場なゼの大深度地下への建設が検討されている.

大深下地下の開発が良好な地山を対象にするのなら問 題は少ないが, 強度の低い地山あるいは強度が大きくて も地山強度比が小さい地山を対象にせざるを得ない場合 も少なからずあると予測される．このような場合，現在 の技術で合理的に対応できるかどうか疑問である．地下 空間建設の核となるトンネルの設計だけを取り上げても 検討, 解決すべき課題が数多くあると思われる.

たとえば，NATM では強度の低い地山における設計 法が必ずしも確立されているとはいえない状態にある.

また，シールド工法では NATM の基本である地山の強

* 正会員 前田建設工業 (株) 土木設計部 （勈2 千代田区富士見 2-10-26）

** 正会員 前田建設工業 (株) 土木設計部 (同上)

** 正会員 工博 東京都立大学教授 工学部土木工学科

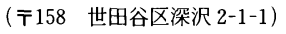

度を積極的に活用しようという設計思想が取り入れられ ていないので, 大深度の地山を対象とした場合, 経済性 を向上させる余地がかなり残っていると思われる.しか も, NATM とシールド工法の適用地山が現在でも一部 重複しており，今後さらにその度合いが高まると予想さ れるので，これらの設計思想を異なったままにしていて は工法の選定などにおいてさまざまな不都合が生じると 思われる.

そこで, 本研究では, 大深度低強度地山における NATM とシールド工法の設計思想を統一し，トンネル の安全性と経済性が両立する合理的な設計法を確立する ための第一歩として, 新しい設計目標 ${ }^{1}$ を提案し, その 有用性の検証を試みた。

\section{2. 現行のトンネル設計法を大深度低強度地山 に適用した場合の問題点}

NATM は地山のもつ強度をできるだけ有効に利用す ることを基本に発達してきた工法 ${ }^{2)}$ である. 適度な変形 を許せば支保工の規模を最小・最適にできることが経験 的に認識されて以来, 支保工に作用する荷重（支保圧） $P_{i}$ と地山変位 $U$ の関係を表わす地山特性曲線（いわゆ るFenner-Pacher曲線）における最小かつ極小の支保 圧 (以後, 最小支保圧) $P_{i \min }$ を求如, これを設計目標, 
施工管理基準とすることが大きな課題 ${ }^{3{ }^{2}}$ となったが，成 果が出ないまま現在に至っている。これは，NATM が 特にその有利さを発揮した良好な地山においては $P_{i \min }$ が存在しない（最小值が極小值を兼ねない）ことに一因 があると考えられる. 結局, 経験豊富な良好な地山に対 しては実績に基づいて地山等級ごとに標準支保パターン が作成されたが4), 類似条件の経験が豊富とはいえない 強度の低い地山に対しては試行錯誤の設計・施工を余儀 無くされている.

一方, シールド工法の場合, 周辺環境対策が優先され ることが多かったため, NATMにおける $P_{i \min }$ のよう な設計目標に対する検討はなされなかった。この工法は 地山を緩めないことを目標に発達してきたが，それをほ とんぞ達成したにもかかわらず，セグメントの設計用鉛 直方向土圧として全土被り圧あるいは Terzaghi の緩み 土圧を採用するのが一般的という現状で5), 工法の特徵 と設計土圧の間に多少食い違いがみられる．浅度地下に おいてはこの食い違いが環境問題と経済性の両立に必要 かつ有効であるかもしれないが, 応力解放が地表面の変 位に及ぼす影響が相対的に小さくなる大深度地下におい ても安全性と経済性の両立に有効であるかどうか疑問で ある.

以上のように, NATM もシールド工法も大深度低強 度地山に合理的に適用するには設計上解決すべき課題が ある、NATM の合理的な設計を考える場合，地下特性 曲線が必要不可欠である. また, シールド工法の場合で も, NATM とシールド工法の境界領域の地山において は，テールボイド分の変位とセグメントに作用する土圧 の関係が地山特性曲線として利用できると考えられる. したがって，この地山特性曲線によって両者の設計が同 じ基盤に乗ることも期待できる. 地山特性曲線上のだの 点を設計目標にすべきか NATM の原点に戻って検討す る必要があると考えられる.

\section{3. 地山特性曲線上の設計目標}

コンクリートによる覆工だけで支保するトンネルを想 定した場合, 覆工の応力が許容值と一致する覆工時期と 覆工厚の組合せは無数にある. トンネル建設の経済性を 追及し，設計の合理化を図るためには，その無数の組合 せの中から最も合理的なものを選出する必要がある.こ の選出の判定基準になるものが設計目標である.

トンネルの施工費を支配するのは掘削と覆工であり， 設計目標はこれらに直結している必要がある．掘削範囲 $R_{0}$ は設計内空と覆工厚と変位の和で表わされ, 覆工厚 は支保圧によって決まる，したがって，設計目標の候補 として最小支保圧 $P_{i \min }$ と最小掘削範囲 $R_{0 \text { min }}$ が挙げら れる.

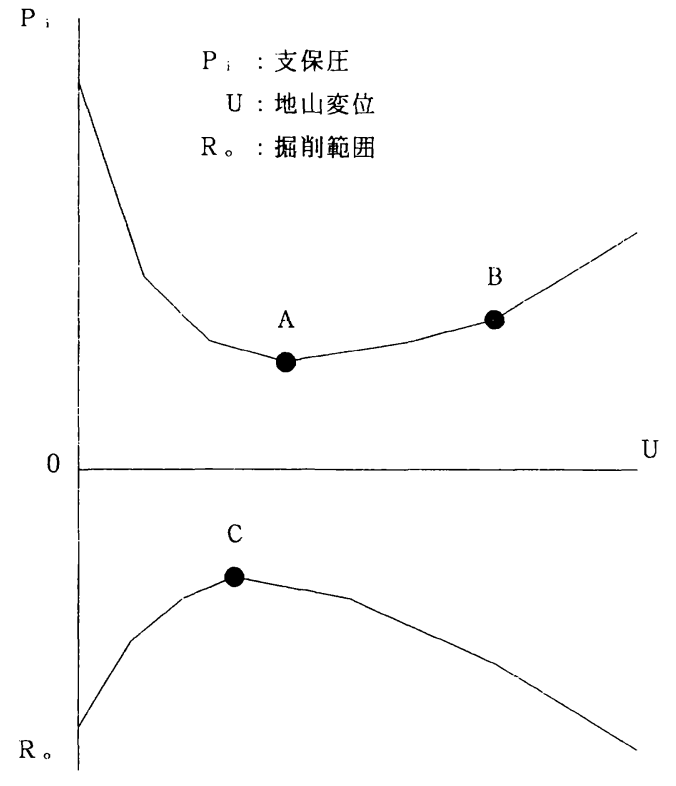

図一1地山特性曲線と掘削特性曲線

図一1の上部に示すような地山特性曲線上の最小支保 圧を与える点を $\mathrm{A}, \mathrm{A}$ より変位の大きい点を $\mathrm{B}$ とする. 覆工の応力が許容值と一致する状態で設計内空を確保す るという条件を付けると，地山特性曲線から図一1の下 部に示すような掘削範囲之変位の関係を表わす曲線に変 換できる.この曲線を, 以後, 掘削特性曲線とよぶこと にする. A と B を比較すると, Aより Bの方が, 変位が 大きい分と大きい支保圧に対して厚い覆工を必要とする 分だけ，大きい掘削範囲を必要とする．このことは地山 特性曲線上のAより変位の大きいすべての点についてい える. したがって, 最小支保圧が存在する地山には最小 かつ極小の掘削範囲 (以後, 最小掘削範囲) $R_{0 \min }$ が存 在し,これを与える点 $\mathrm{C}$ の変位は $\mathrm{A}$ の変位以下になるは ずである.

今まで最適設計目標は地山特性曲線上の最小支保圧 ${ }^{6)}$ であると考えられてきたが，その検証はまだなされてい ない，最小支保圧と最小掘削範囲が同時に実現できれば 理想的だが, その可能性は不明である. 上記の考察によ れば, 最小掘削範囲に対応する覆工厚は最小支保圧のそ れ以上になるが, 最小掘削範囲は最小支保圧に対応する 掘削範囲以下になる．補強工なしでは大きな変位が生じ て掘進が困難になる大深度低強度地山におけるトンネル では掘削量の少なさが覆工の厚い分を補う可能性があ る. 最小支保圧と最小掘削範囲の設計目標としての有用 性を比較検討する必要がある。 


\section{4. 最小支保圧と最小掘削範囲}

\section{（1）地山特性曲線と掘削特性曲線の作成方法}

最小支保圧と最小掘削範囲の特性を解析的に検討する ために, 以下の仮定を設けて地山特性曲線と掘削特性曲 線を作成する.

(1) 地山は等方等質で, 初期地圧は等方一様に分布す る.

(2) トンネルは円形断面で, 平面ひずみ状態にある. したがって, 以下，掘削範囲は掘削半径で表わされ る.

(3) 弾性域地山の強度降伏条件亡塑性域地山の降伏応 力条件は式（1）と式（2）で定義される.

$$
\tau=C_{p}+\sigma \cdot \tan \left(\phi_{p}\right)
$$

$\tau=C_{r}+\sigma \cdot \tan \left(\phi_{r}\right)$

ここに, $\tau$ : せん断応力, $\sigma$ : 垂直応力, $C_{p}:$ ピ一 ク強度時の粘着力, $\phi_{p}:$ ピーク強度時の 内部摩擦角, $C_{r}$ : 残留強度時の粘着力, $\phi_{r}:$ 残留強度時の内部摩擦角

(4) 応力がピーク強度以下のとき地山は線形弾性体之 して挙動する. ピーク強度に達すると地山の支保能 力は残留強度まで急激に低下し，その後は一定を保 つ.

(5) 塑性領域で発生する体積膨張は平均体積ひずみで 表わされる.

これらの仮定の下で, 弾性理論と Kastner の応力解を 適用すると ${ }^{71,8)}$, 弾塑性境界の半径 $R_{a}$ と変位 $U_{a}$ は式 （3）と式（4）で表わされる.

$$
R_{a}=R\left\{\left(\sigma_{r a}+\lambda Q_{r}\right) /\left(P+\lambda Q_{r}\right)\right\}^{\lambda}
$$

$U_{a}=R_{a}\left(\sigma_{0}-\sigma_{r a}\right)(1+\nu) / E$

ここに, $\sigma_{r a}=\left(2 \sigma_{0}-Q_{p}\right) /(1+\xi)$

$Q_{p}=2 C_{\rho} \cos \left(\phi_{\rho}\right) /\left(1-\sin \left(\phi_{p}\right)\right)$

$Q_{r}=2 C_{r} \cos \left(\phi_{r}\right) /\left(1-\sin \left(\phi_{r}\right)\right)$

$\lambda=\left(1-\sin \left(\phi_{r}\right)\right) / 2 / \sin \left(\phi_{r}\right)$

$\xi=\left(1+\sin \left(\phi_{p}\right)\right) /\left(1-\sin \left(\phi_{p}\right)\right)$

$R$ : 掘削半径, $\sigma_{r a}$ : 弾塑性境界の半径方向応 力, $E:$ 地山の弾性係数, $\sigma_{0}$ : 初期地圧, $P$ ：トンネル壁面に作用する支 保圧 (塑性領域の重量は無視)

弾性領域が弾塑性境界で $U_{a}$ だけ内空に向かって変位 した結果, 塑性領域が体積膨張しながら内空に向かって 押し出されると考えると ${ }^{9}$, トンネル壁面の地山変位 $U$ は式 (5・a) で表わされる.ただし, 塑性領域が発生し ない場合には式 $(5 \cdot \mathrm{b})$ で表わされる.

$$
\begin{gathered}
U=R-\left\{\left(R_{a}-U_{a}\right)^{2}-(1+e)\left(R_{a}^{2}-R^{2}\right)\right\}^{1 / 2} \\
\left(P \leqq \sigma_{r a} \text { のとき }\right) \cdots \cdots \cdots \cdots \\
U=R\left(\sigma_{0}-P\right)(1+\nu) / E
\end{gathered}
$$

$$
\text { ( } P \geqq \sigma_{r a} \text { のとき) }
$$

ここに, $e:$ 体積膨張に伴う平均体積ひずみ (正が膨張)

塑性領域のような不安定な領域の大部分は人工的に支 保する必要がある．このことは上記の $P$ では考慮され ていない. P. Gesta ${ }^{10)}$, Hoek and Brown ${ }^{111}$ などの考元 に従って, 式（6）に示すように, 塑性領域の自重を付 加した支保圧 $P_{i}$ を地山特性曲線の支保圧とする.

$$
P_{i}=P+\left(R_{a}-R\right) \gamma
$$

ここに, $P_{i}$ : 塑性領域の重量を考慮した支保圧

$$
\gamma: \text { 地山の単位体積重量 }
$$

ただし，この $P_{i}$ はトンネルの天端に対応するもので, 他の部分より大きく, 式 (6) は最小支保圧の存在する 可能性を大きくする補正であることに注意する必要があ る.

$P\left(0 \leqq P \leqq \sigma_{0}\right)$ をパラメーターにして式（3)（６） により $P_{i}$ と $U$ を求めると地山特性曲線が作成できる.

覆工応力が許容値と一致する状態で設計内空を確保す るためには，式（7）と式（8）で表わされる覆工厚 $T$ と掘削半径 $R_{0}$ が必要である．ただし，ロックボルト の効果の評価方法がまだ確立されていないので，支保は コンクリートによる覆工のみとする．また，覆工が負担 すべき支保圧は $P$ とし, 覆工は剛な薄肉円筒とする.

$$
\begin{aligned}
& T=R_{i} P /\left(\sigma_{c a}-P\right) \\
& R_{0}=R_{i} \sigma_{c a} /(1-U / R) /\left(\sigma_{c a}-P\right)
\end{aligned}
$$

ここに, $R_{i}$ : 設計内空半径, $\sigma_{c a}$ : 覆工応力の許容値

$P\left(0 \leqq P \leqq \sigma_{0}\right)$ をパラメーターにして地山特性曲線 の $U / R$ を式 $(8)$ に代入すると掘削特性曲線が作成で きる.

\section{（2）地山特性曲線と最小支保圧の例}

表-1 の計算条件に対応して式（3)（６）により得 られる地山特性曲線を図一2〜7に示す。図中の口 と $\triangle$ は弾性限界と最小支保圧を与える点で，（）内は Case を表わす。なお，折瓜トンネルなど膨張性地山に おけるトンネルの実績から検討する変位の上限值 $U_{z}$ を $U_{z} / R=0.4$ と設定している.

図一2 は強度低下がない場合に内部摩擦角が地山特性 曲線に及ぼす影響を表わしている．地山強度比が小さい ほど，また，地山強度比が一定でも内部摩擦角が小さい ほど弾性限界の支保圧は大きく, それを与える変位は小 さい. 最小支保圧は地山強度比が小さく, しかも, 内部 摩擦角が小さいときにのみ存在する。この場合, 最小支 保圧は弾性限界のそれと大きな違いはないが, 最小支保 圧を与える変位は弾性限界のそれよりかなり大きい.

図一3は強度低下が地山特性曲線に及ぼす影響を表わ している. 強度低下が大きいほど最小支保圧の存在する 可能性が高いが, 弾性限界は強度低下の影響を受けない。

図一4はトンネルの大きさが地山特性曲線に及ぼす影 
表一1 計算条件

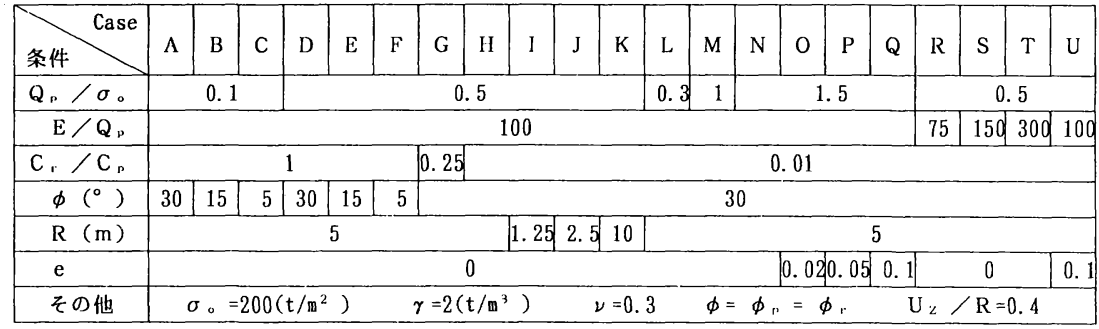

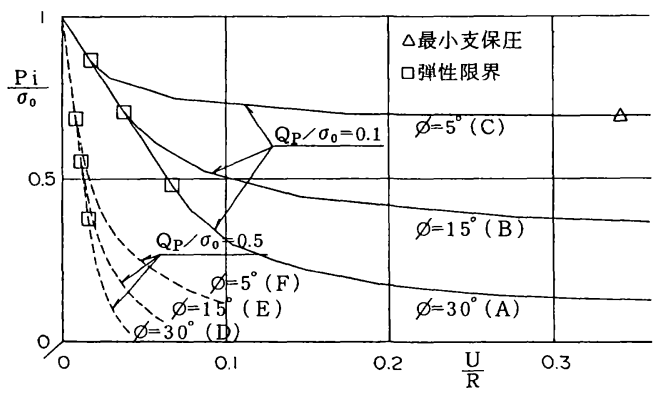

図一2 地山特性曲線と内部摩擦角の関係

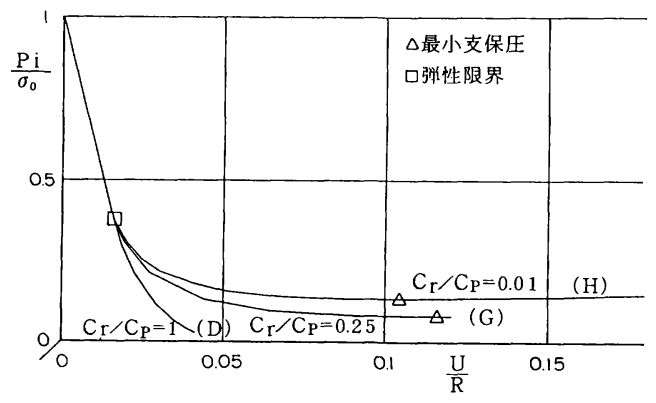

図一－地山特性曲線と強度低下の関係

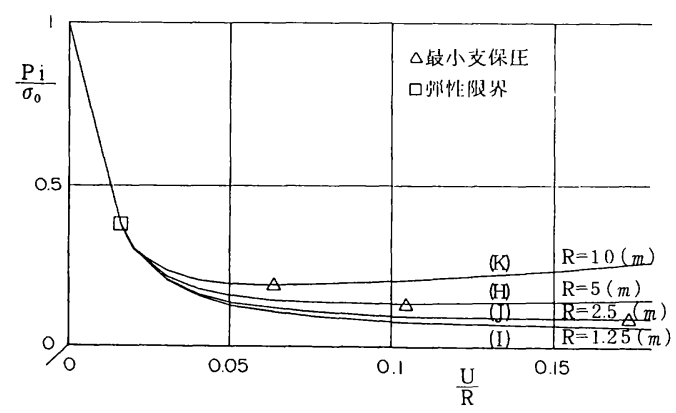

図一4＼cjkstart地山特性曲線とトンネルの大きさの関係

響を表わしている. トンネルの半径（掘削半径）が小さ いほビ最小支保圧の変位/トンネル半径は大きく, 支保 圧は小さい.これに対し, 弾性限界はトンネルの大きさ の影響を受けない。

図一5 は強度低下があり, 土被りが一定の場合に地山

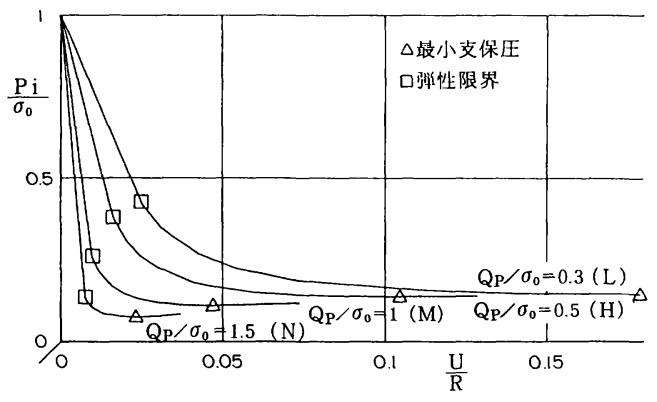

図一5 地山特性曲線と地山強度比の関係

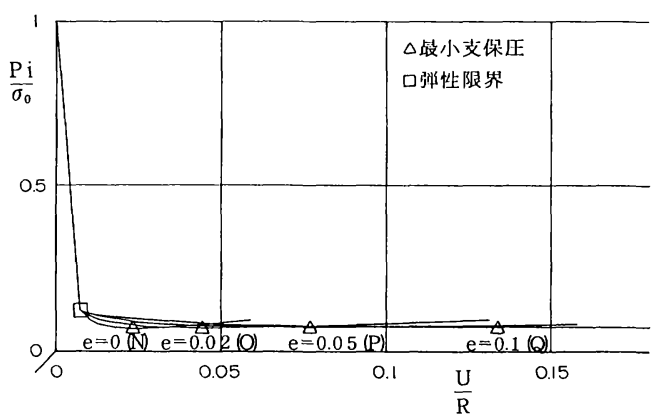

図一6 地山特性曲線と体積膨張の関係

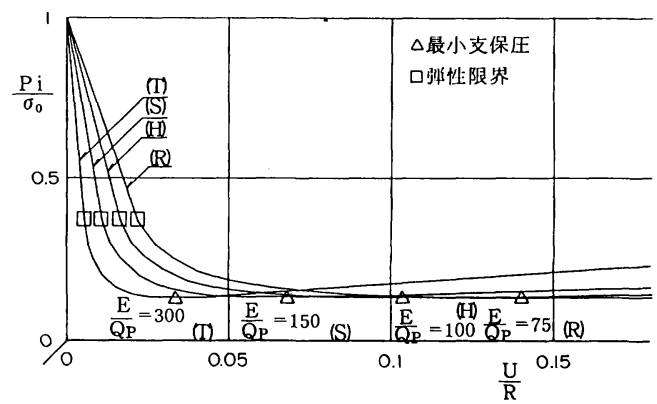

図-7 地山特性曲線と変形係数比の関係

強度比が地山特性曲線に及ぼす影響を表わしている．大 きな強度低下がある場合には地山強度比が大きいほど最 小支保圧亡弾性限界の支保圧およびこれらを与える変位 は小さく，両者は近接する.

図一6 は強度低下に伴う体積膨張が地山特性曲線に及 
ぼす影響を表わしている．最小支保圧の值そのものは体 積膨張の影響を受けないが, 体積膨張が大きいほよ゙最小 支保圧を与える変位は大きい。

図一7 は変形係数比 $Q_{p} / E$ が地山特性曲線に及ぼす影 響を表わしている．地山強度比と強度低下の大きさが同 じであれば変形係数比が変化しても弾性限界の支保圧と 最小支保圧は変化しない，弾性限界を与える変位は変形 係数比に完全に反比例し，最小支保圧を与える変位もほ ぼ反比例する。

結局，これらの図から次のことが推察される.

(1) 地山特性曲線上に最小支.保圧が存在するのは強度 低下がある場合にほほ限られる，強度低下が大きい 場合には地山強度比が 2 に近くても存在する可能性 が高い.

(2) 強度低下がなくても地山強度比と内部摩擦角が小 さい場合には最小支保圧の存在する可能性がある。

(3) 最小支保圧はトンネルが大きい方が存在する可能 性が高い。

(4) 最小支保圧は明瞭な極值にはならない.

(5)一般に，最小支保圧は小さいが，それを与える変 位は大きい。弾性限界の支保圧は大きいが，それを 与える変位は小さい．両者が近接するのは強度低下 と地山強度比とトンネルが大きい場合だけである。

(6) 体積膨張は最小支保圧を与える変位を大きくし， 最小支保圧の存在する地山条件の範囲を小さくす る.

(7) 変形係数比が大きい硬岩タイプの地山ほよ゙, 変位 が上限值 $U_{z}$ を越える可能性が低く, 強度低下が大 きいと考えられるので，最小支保圧の存在する可能 性が高い。

\section{（３）掘削特性曲線と最小掘削範囲の例}

Case A, H, U の計算条件に対応する掘削特性曲線を 図一8に示す. 図中の○は最小掘削半径 $R_{0 \min }$ を与える 点である.ただし， $R_{i}=5(\mathrm{~m}), \sigma_{c a}=600\left(\mathrm{t} / \mathrm{m}^{2}\right)$ とし ている.

Case A の地山特性曲線には最小支保圧が存在しない が, 掘削特性曲線には最小掘削範囲が存在する. Case $\mathrm{H}$ の最小掘削範囲を与える変位は最小支保圧のそれよ りはるかに小さい. Case U は Case H に体積膨張が加 わったものだが, Case H より最小掘削範囲を与える変 位は小さく, 最小支保圧を与える変位は限界変位を越え てしまう。

結局，図一2 7および図一8から次のことが推察され る.

(1) 最小支保圧の存在する地山条件の範囲は最小掘削 範囲のそれより小さい。

(2) 最小掘削範囲を与える最小支保圧のそれより小さ

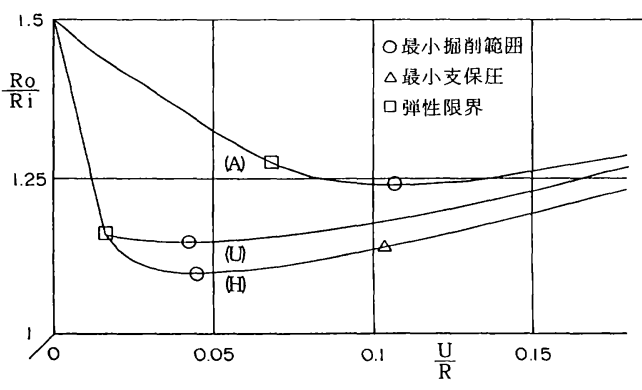

図一8 掘削特性曲線

W.

(3) 体積䐍張は最小掘削範囲を与える変位を小さく し，最小支保圧のそれを大きくする.

\section{（4）最小支保圧と最小掘削範囲の存在判別と変位}

地山特性曲線上の最小支保圧 $P_{i \min }$ の近傍は明瞭な谷 部を形成しないので $P_{i \min }$ が存在しているのかだうか, $P_{i \min }$ を与える点がゼれなのか図上では判然としない. そこで, $P_{i \min }$ 存在の判別式と変位の計算式を導く.

$P_{i \min }$ は塑性領域が発生しなければ存在しない. $P=$ $\sigma_{r a}$ を式 $(5 \cdot \mathrm{b})$ に代入して得られる $U$ を $U_{E P}, P=0$ を 式 ( 3 ) (5・a) に代入して得られる $U$ を $U_{P O}$ とすると, $U$ と $P_{i}$ の関係は, $U_{P O}>U>U_{E P}$ のとき, 式 $(3) \sim(6)$ により式（9）で表わすことができる.

$$
P_{i}=a_{2} X^{-1 / \lambda}-a_{3}+a_{4}(X-1) \text {. }
$$

ここに, $a_{1}=1-\left(1-a_{5}\right)^{2}, a_{2}=\sigma_{r a}+a_{3}, a_{3}=\lambda Q_{r}$,

$$
\begin{aligned}
& a_{4}=\gamma R, \quad a_{5}=\left(\sigma_{0}-\sigma_{r a}\right)(1+\nu) / E \\
& X=\left\{(x+e) /\left(a_{1}+e\right)\right\}^{1 / 2}, \quad x=1-(1-U / R)^{2}
\end{aligned}
$$

この $P_{i}$ を極小にする変位 $U_{P M P}$ は $d P_{i} / d U=0$ を解くこ とにより式 (10) で与えられる.

$$
U_{P M P}=R\left\{1-\left(1-a_{6}\right)^{1 / 2}\right\} \text {. }
$$

ここに, $a_{6}=\left(a_{1}+e\right)\left(a_{2} / a_{4} / \lambda\right)^{2 \lambda /(1+\lambda)}-e$

$P_{i \min }$ を与える変位 $U_{P M}$ は, $U_{P O}>U_{P M P}>U_{E P}$ のとき $U_{P M P}$ だが， $U_{P M P} \leqq U_{E P}$ のときは $U_{E P}$ である。このとき地 山特性曲線の $P_{i}$ は, $U \leqq U_{E P}$ の $U$ に対しては塑性領域 が発生しないために $U$ が大きくなるとともに小さくな り, 地山特性曲線が式（9）で表わされる $U>U_{E P}$ の $U$ に対しては $U_{P M P} \leqq U_{E P}$ であるために $U$ が大きくなる とともに大きくなるからである．また， $U_{P M} \geqq U_{Z}$ となる ことは仮定より許されない，したがって， $P_{i \min }$ が存在 するのは式（11）または式（12）が成立するときに限ら れ, $U_{P M}$ は式 (13) で与えられる.

$$
2 \sigma_{0}>Q_{\rho} \text { かつ } U_{P O}>U_{P M P}>U_{E P} \text { かつ } U_{Z}>U_{P M P}>0
$$

$2 \sigma_{0}>Q_{\rho}$ かつ $U_{Z}>U_{E P} \geqq U_{P M P}$

$U_{P M}=U_{P M P} \quad($ 式 $(11)$ が成立するとき $) \cdots \cdots(13 \cdot a)$
$U_{P M}=U_{F P} \quad($ 式 $(12)$ が成立するとき $) \cdots \cdots(13 \cdot \mathrm{b})$ 
次に, $P_{i \min }$ と同様に $R_{0 \min }$ 存在の判別式と変位の計 算式を導く

$R_{0}$ と $U$ の関係は式 $(3) \sim(5)$ と式（8）により式 (14）で表わすことができる.

$$
R_{0}=c b_{1} / y /\left(1+b_{2}-y\right) \quad\left(U \leqq U_{E P} \text { のとき }\right)
$$

$$
R_{0}=c / y /\left(b_{3}-b_{4} Y^{-1 / 2 / \lambda}\right) \quad\left(U \geqq U_{E P} \text { のとき }\right)
$$

ここに, $b_{1}=(1+\nu) / E, \quad b_{2}=b_{1}\left(\sigma_{c a}-\sigma_{0}\right), \quad b_{3}=\sigma_{c a}+a_{3}$

$b_{4}=a_{2}\left(a_{1}+e\right)^{1 / 2 / \lambda}, \quad c=R_{i} \sigma_{c a}$

$$
y=1-U / R, \quad Y=1+e-y^{2}
$$

$R_{0}$ を極小にする変位は $d R_{0} / d U=0$ を解くことにより, 式 (14·a) に対しては式 (15), 式 $(14 \cdot b)$ に対しては 式 (16) で与えられる.

$$
\begin{aligned}
& U_{R M E}=R\left(1-b_{2}\right) / 2 \cdots \cdots \cdots \cdots . . . . . . \\
& U_{R M P}=R\left\{1-\left(1+e-Y_{0}\right)^{1 / 2}\right\}
\end{aligned}
$$

ここに, $Y_{0}:$ 式 $(14 \cdot \mathrm{b})$ を $U$ で微分した式を 0 とおい て得られる式 (17) を満足する $Y$

$$
b_{3}-b_{4}(1-1 / \lambda) Y^{-1 / 2 / \lambda}-b_{4}(1+e) Y^{-1 / 2 / \lambda-1} / \lambda=0
$$

$R_{0 \min }$ を与える変位 $U_{R M}$ は, $U_{E P}>U_{R M E}>0$ のときは $U_{R M E}, \quad U_{P O}>U_{R M P}>U_{E P}$ のときは $U_{R M P}$ だが, $U_{E P} \geqq U_{R M P}$ かつ $U_{R M E} \geqq U_{E P}$ のときは $U_{E P}$ である.このとき $R_{0}-U$ 曲線の $R_{0}$ は, 曲線が式 $(14 \cdot \mathrm{a})$ で表わされる $U \leqq U_{E P}$ の $U$ に対しては $U_{E P} \leqq U_{R M E}$ ということで $U$ が大きくな るとともに小さくなり，曲線が式 $(14 \cdot b)$ で表わされ る $U \geqq U_{E P}$ の $U$ に対しては $U_{E P} \geqq U_{R M P}$ ということで $U$ が大きくなるとともに大きくなるからである，また，上 記の $P_{i \min }$ の場合と同様に $U_{R M} \geqq U_{z}$ となることは許され ない.したがって， $R_{0 \min }$ が存在するのは式 $(18) \sim(20)$ のビれか 1 つが成立するときに限られ， $U_{R M}$ は式 $(21)$ で与えられる。

$$
\begin{aligned}
& U_{P O}>U_{R M P}>U_{E P} \text { かつ } U_{Z}>U_{R M P} \\
& U_{E P}>U_{R M E}>0 \text { かつ } U_{\mathrm{Z}}>U_{R M E} \\
& U_{R M E} \geqq U_{E P} \geqq U_{R M P} \text { かつ } U_{Z}>U_{E P}
\end{aligned}
$$

\begin{tabular}{|c|c|c|c|c|c|c|}
\hline 条件 & 9 & 10 & 11 & 12 & 13 & 14 \\
\hline$\sigma \circ\left(\mathrm{t} / \mathrm{m}^{2}\right)$ & 200 & $\star$ & \multicolumn{4}{|c|}{200} \\
\hline$E / Q_{p}$ & \multicolumn{4}{|c|}{100} & $\star$ & 100 \\
\hline $\mathrm{C}_{\mathrm{r}} / \mathrm{C}_{\mathrm{p}}$ & $\star$ & 1 & & 0.25 & & $\star$ \\
\hline$\phi\left({ }^{\circ}\right)$ & \multicolumn{5}{|c|}{$\star$} & 30 \\
\hline$R(m)$ & & 5 & $\star$ & \multicolumn{3}{|c|}{5} \\
\hline $\mathrm{e}$ & \multicolumn{3}{|c|}{0} & $\star$ & 0 & $\star$ \\
\hline 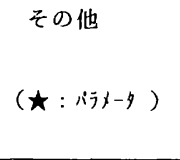 & \multicolumn{6}{|c|}{$\begin{array}{l}\gamma=2\left(\mathrm{t} / \mathrm{m}^{3}\right) \quad \mathrm{R}=\mathrm{R}_{\mathrm{i}} \\
\phi=\phi_{\mathrm{b}}=\phi_{\mathrm{r}} \quad \nu=0.3 \\
\sigma_{\mathrm{c} \mathrm{a}}=600\left(\mathrm{t} / \mathrm{m}^{2}\right) \\
\mathrm{U}_{\%} / \mathrm{R}=0.4\end{array}$} \\
\hline
\end{tabular}

\section{（5）最小支保圧と最小掘削範囲の特性の比較}

式 (11) （21）により, 最小支保圧と最小掘削範囲が 存在する地山条件は図一9１3，それらを与える変位は 図一14に示すようになる.図の作成条件を表一2に示す。

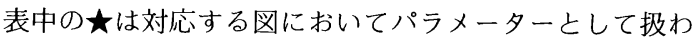
れていることを示す。

図一9 は強度低下が最小支保圧と最小掘削範囲の存在 する地山条件に及ぼす影響を表わしている．矢印を両端

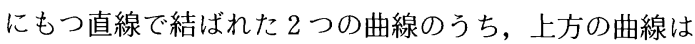

表一2 図の作成条件

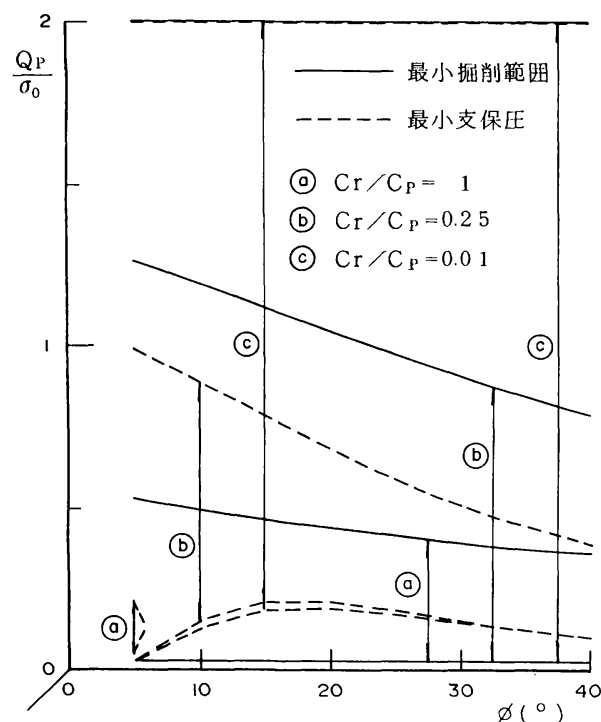

図一9 最小支保圧と最小掘削範囲の存在する地山条件と強度低 下の関係

内部摩擦角に対応して最小支保圧あるいは最小掘削範囲 が存在する地山強度比の上限値を示し，下方の曲線は下 限值を示す．上限值を示す曲線より上方では支保圧 $P_{i}$ と掘削範囲 $R_{0}$ のどちらも $P=0$ のときに最小になる. ただし， $P_{i}$ の場合，強度低下がないときなぼ地山条件 によっては最小支保圧を与える変位 $U_{P M}$ が $U_{P M} / R \geqq 0.4$ になることもある．下限値を示す曲線の下方では $P_{i}$ の 場合 $U_{P M} / R \geqq 0.4$ になり, $R_{0}$ の場合 $P=\sigma_{0}$ のときに最 小になる.これらのことは図一10 13でも同様である.

強度低下が大きいほど最小支保圧と最小掘削範囲の存 在する地山強度比の範囲は大きいが, 前者より後者の方 が強度低下の大小にかかわらず大きい.

図一10は初期地圧あるいは土被りが最小支保圧之最 小掘削範囲の存在する地山条件に及ぼす影響を表わして いる．地圧が大きいほよ゙あるいは土被りが大きいほどそ 


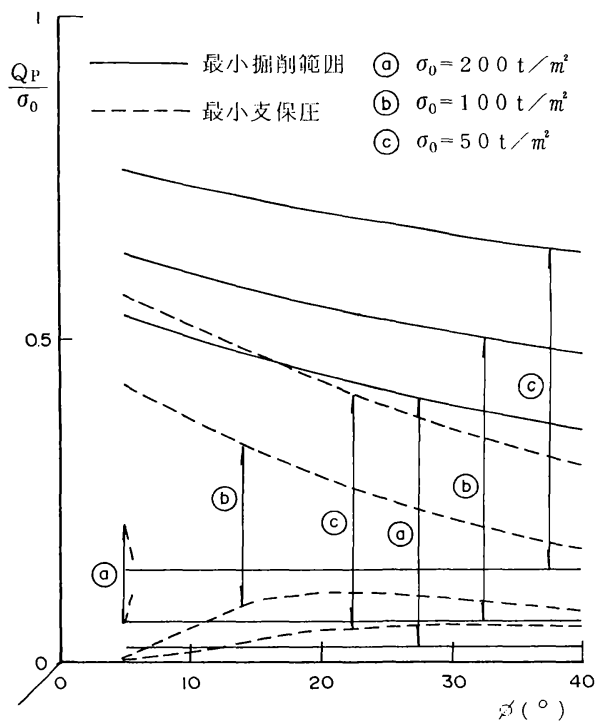

図一10 最小支保圧と最小掘削範囲の存在する地山条件と初期 地压の関係

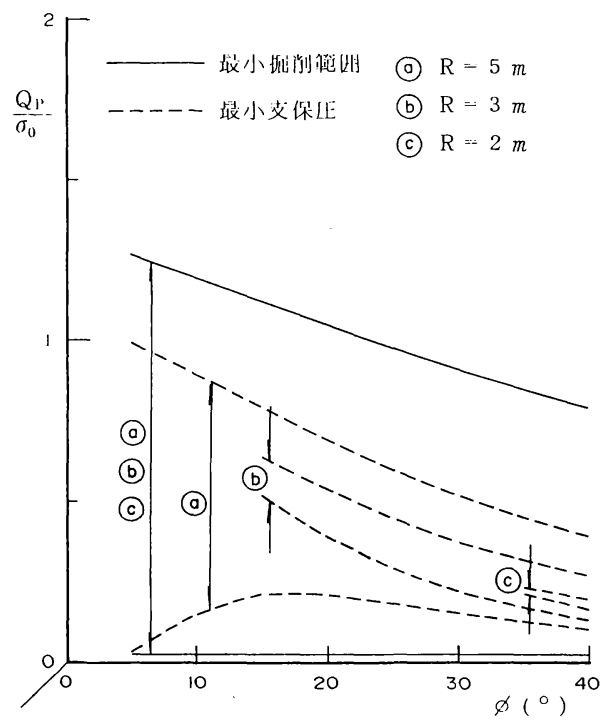

図一11最小支保圧と最小掘削範囲の存在する地山条件とトン ネルの大きさの関係

れらの存在する地山強度比の範囲は小さい.

図一11 はトンネルの大きさが最小支保圧と最小掘削 範囲の存在する地山条件に及ぼす影響を表わしている. トンネルが小さいほど最小支保圧の存在する地山強度比 の範囲は小さいが, 最小掘削範囲のそれは変化しない. これは, 地山特性曲線の支保圧 $P_{i}$ が塑性領域の重量を 付加した天端における支保圧であるのに対し， $R_{0}$ の算 出に用いる支保圧はそれを付加していない $P$ (側壁に

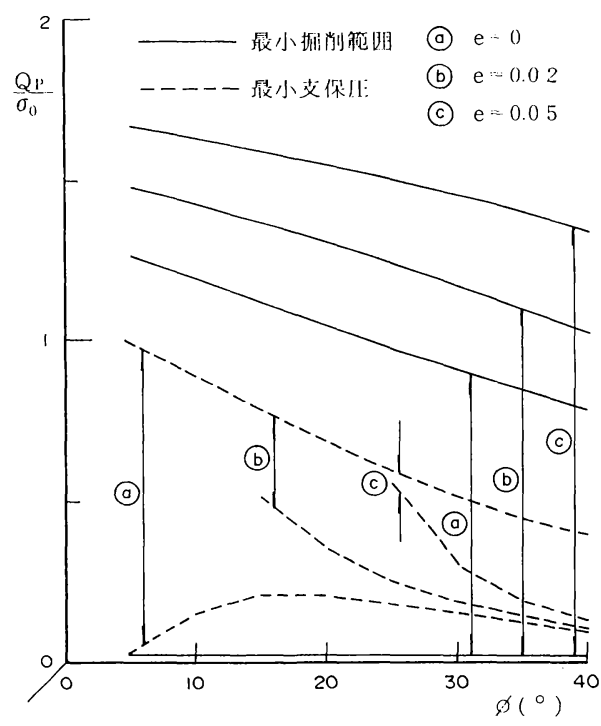

図一12 最小支保圧と最小掘削範囲の存在する地山条件と体積 膨張の関係

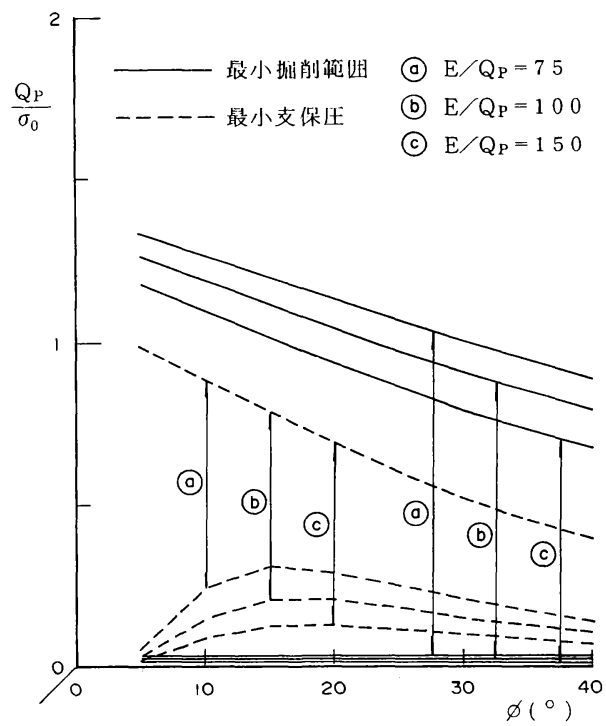

図一13最小支保圧と最小掘削範囲の存在する地山条件と変形 係数比の関係

おける支保圧に対応) であることによる. トンネルが小 さい場合, 最小支保圧の存在する地山強度比の範囲は最 小掘削範囲のそれと比べてはるかに小さく, 内部摩擦角 が小さいときには存在しない.

図一12 は強度低下に伴う体積膨張が最小支保圧と最 小掘削範囲の存在する地山条件に及ぼす影響を表わして いる、体積膨張に伴う平均体積ひずみ $e$ が大きいほど 最小掘削範囲の存在する地山強度比の範囲は大きいのに 


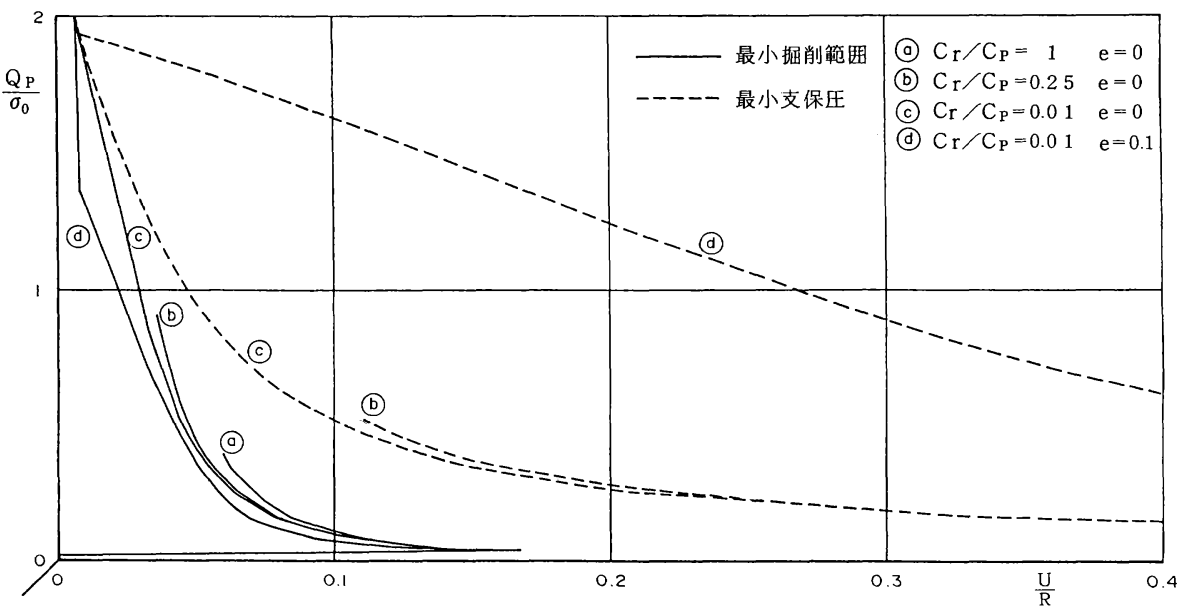

図一14 最小支保圧と最小掘削範囲を与える変位

対し, 最小支保圧のそれは小さく, 内部摩擦角が小さい ときには存在しない.

図一13 は変形係数比が最小支保圧と最小掘削範囲の 存在する地山条件に及ぼす影響を表わしている. 変形係 数比が大きいほよ゙最小支保圧の存在する地山強度比の範 囲は大きいのに対し, 最小掘削範囲のそれは小さい。し かし, 変形係数比が 150 の場合でも最小支保圧のそれよ り最小掘削範囲のそれの方が大きい.

図一14 は最小支保圧と最小掘削範囲を与える変位と 地山強度比との関係を表わしている．強度低下によって 最小支保圧と最小掘削範囲の存在する地山強度比の範囲 は大きくなるが, それらを与える変位はほとんど変化し ない. また, 最小支保圧を与える変位は地山強度比が小 さいほど大きいのに対し, 最小掘削範囲のそれは, 地山 強度比がある值以上のときには地山強度比が小さいほど 大きく, それ以下のときには地山強度比が小さいほど小 さい.これは，大きな変位を許しては最小掘削範囲には ならないということであり, 式 (19) あるいは式 $(21 \cdot b)$ からわかるように, 塑性領域が発生する場合だけではな く, 発生しない場合にも最小掘削範囲の存在する可能性 があることに起因する.また，最小掘削範囲を与える変 位に及ぼす体積膨張の影響は小さいが, 最小支保圧のそ れは大きい. しかも, 最小掘削範囲を与える変位は平均 体積ひずみ $e$ によって小さくなるのに対し, 最小支保 圧のそれは非常に大きくなる，両者の值がほぼ一致する のは強度低下が大きく, 地山強度比が 2 に近い場合に限 られる。

以上から得られる重要なことを整理すると次のように なる.

(1) 最小掘削範囲の存在する地山条件の範囲は最小支 保圧のそれよりはるかに大きく, 最小掘削範囲を与 える変位は最小支保圧のそれより小さい, 両者の值
がほぼ一致するのは強度低下が大きく, 地山強度比 が 2 に近い場合に限られる.

(2) 大深度になるほど最小掘削範囲亡最小支保圧の存 在する地山条件の範囲は小さくなるが, その度合い は最小掘削範囲の方が小さい.

(3) 体積膨張は最小支保圧の存在する地山条件の範囲 を小さくし，それを与える変位を大きくするが，最 小掘削範囲に対しては存在する地山条件の範囲を大 きくし，それを与える変位を小さくする.

(4) トンネルが小さいほど最小支保圧の存在する可能 性は低いが，最小掘削範囲はその影響を受けない。

これらのことから, 大深度低強度地山では最小支保圧 より最小掘削範囲の方が設計目標に適している可能性が 高いと判断される.

\section{5. 大深度低強度地山におけるトンネルの最適 設計目標}

ここでは施工費に直結する指標として式（22）で表わ される $F$ を用いて最適目標について検討する.

$F=\left\{\pi R_{0}^{2} W_{E}+2 \pi T\left(R_{i}+T / 2\right) W_{L}\right\} /\left(\pi R_{i}^{2} W_{E}\right)$

ここに, $W_{E}$ : 掘削単価, $W_{L}$ : 覆工単価

この $F$ は設計内空の掘削費が 1 になるように無次元化 しており，Fが小さく，1に近いほど施工費が安く, 合 理化度が高いことを表わす。

$P$ をパラメーターにして, 式 (7) と式 (8) に地 山特性曲線の $U / R$ を代入して得られる $T$ と $R_{0}$ を式 （22）に代入すると, 施工費と変位の関係を表わす曲線 が作成できる. 以後, この曲線を合理化特性曲線とよぶ ことにする.

Case H, N, Q（および $\mathrm{H}^{\prime}$ ）の計算条件に対応する合 理化特性曲線を図一15に示す.ただし， $R_{i}=5 \mathrm{~m}$, Case H, N, Q では $\sigma_{c a}=600 \mathrm{t} / \mathrm{m}^{2}$, Case $\mathrm{H}^{\prime}$ では $\sigma_{\mathrm{ca} a}=1$ 


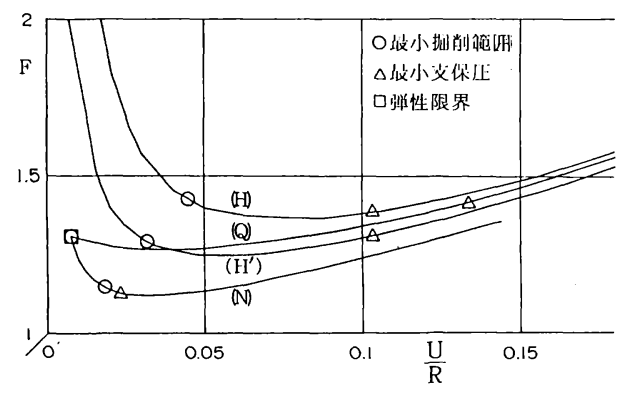

図一15 合理化特性曲線

$200 \mathrm{t} / \mathrm{m}^{2}$ としている. Case $\mathrm{H}$ と Case $\mathrm{H}^{\prime}$ の違いは $\sigma_{c a}$ の值だけである。 また， $W_{L}$ と $W_{E}$ の比 $W_{L} / W_{E}$ は $3.5 /$ 1.5 としている.

Case $\mathrm{H}$ と Case $\mathrm{N}$ の合理化特性曲線では最小掘削範 囲より最小支保圧の方が対応する施工費指標 $F$ の值が 小さいものの，大きな差はない. しかも，Case Q のよ うにCase $\mathrm{N}$ に体積膨張が加わると，また，Case $\mathrm{H}^{\prime}$ の ようにCase H $の \sigma_{c a}$ を大きくすると，両者は逆転する.

また，どの合理化特性曲線でも施工費指標 $F$ の最小 值と最小掘削範囲に対応する $F$ との間にはわずかな差 しかみられない．しかも，Fの最小值を与える点の変 位は最小掘削範囲のそれより大きい，施工費が同じよう な值になるのならば，変位が小さく，覆工が厚くなる最 小掘削範囲を設計目標にすべきである，大深度低強度地 山におけるトンネルの設計目標として最小掘削範囲が最 も合理的であると判断される，ただし，掘削単価と覆工 単価は深度など地山条件，施工条件によって変化する。 両者の比が変化すれば合理化特性曲線の形状も変化す る.トンネルの設計目標を設定するときにはこの点に注 意する必要がある.

\section{6. 結 論}

本研究は，近い将来に必要になると考えられる大深度 低強度地山の開発に備えて, NATM とシールド工法の 設計思想を統一し，トンネルの安全性と経済性が両立す る合理的な設計法を確立するための基盤作りを目的に 行ったものである.今までトンネルの設計目標として地 山特性曲線上の最小支保圧が注目されてきたが，これは 支保部材の量を最少にする役目を果たすものである．経 済性を追及するためには，支保部材の量（あるいは覆工 厚）だけではなく，掘削量も考慮する必要がある。そこ で, 単純化, 理想化した条件の下で, 地山特性曲線を作 成し，さらに，この曲線から掘削特性曲線と合理化特性 曲線を作成して，何を設計目標とすべきか検討した。そ の結果明らかになった主要なことを次に列挙する.

(1) 最小支保圧よりも最小掘削範囲の方がはるかに広
範囲の地山に存在する．最小支保圧が存在するのは 強度低下がある場合にほぼ限られる。

(2) 最小掘削範囲を与える変位は最小支保圧のそれよ り小さい，両者の変位がほぼ一致するのは強度低下 が大きく，地山強度比が 2 に近い場合に限られる。

(3) 最小掘削範囲之最小支保圧に対応する施工費には 大きな差はみられない，覆工の強度や体積膨張の有 無によって両者が逆転する場合もある.

(4) 最小掘削範囲に対応する施工費と最小施工費との 間にはわずかな差しかみられない。しかも，最小掘 削範囲を与える変位は最小施工費のそれより小さ い. 同じような施工費であるならば, 変位が小さく, 覆工が厚くなる最小掘削範囲を設計目標にすべきで ある.

掘削量と支保部材は少なければ少ないほど経済性が高 くなる．安全性を確保したうえで両者を最少にできれば 申し分ないが，上記の検討によれば，それはきわめて限 られた地山条件のときにしか実現せず，一般的には支保 部材より掘削量を最少にした方がトンネルの安全性と経 済性の両立に結びつくと考えられる.

なお，トンネルの最小掘削範囲を設計目標とした設計 法の妥当性をさらに検討するためにはより現実的な地山 特性曲線が必要である. 現場計測結果の逆解析による地 山特性曲線の作成などが今後の課題であると考えられ る.

\section{参 考 文 献}

1）梨本 裕・高森貞彦：NATMにおける設計目標の合理化 〈必要最小掘削径〉, 第 22 回岩盤力学に関するシンポジ ウム講演論文集, pp. 126〜130, 1990. 2.

2) 高山 昭 (監修) : NATM の理論と実際, 土木工学社.

3）谷本親伯：NATM における情報化施工, 土と基礎, 30-7 (294), pp. 63 70, 1982.7 .

4) 土木学会：トンネル標準示方書 (山岳トンネル編) ・同解 説.

5) 土木学会：トンネル標準示方書 (シールド編) ・同解説.

6）岡 行俊：NATMにおける支保理論，施工技術，10-11, pp. 6 12, 1977.

7) Kastner, H. : トンネルの力学 (金原 弘訳), 森北出版, 1974.

8）今田 徹：トンネルの支保構造に関する構造力学的研究, 1980. 7 .

9）土質工学会：堆積軟岩の工学的性質とその応用, 土質基 礎工学ライブラリー 30 .

10) Gesta, P. : Recommendations for Use of ConvergenceConfinement Method (Tunnels et Ouvrages Souterrains No.73, Janvier-Fevrier 1986) 作業グループ 7.

11) Hoek, E. and Brown, E. T. : 岩盤地下空洞の設計と施 工, 土木工学社, 1985.

(1990.10.23 - 受付) 